\title{
Does Effectiveness of Training Program Influenced Teachers' Job Performance? Evidence from Malaysia
}

\author{
${ }^{*}$ Shirley Ken Tzu Ting1, Cheah Yeh Ying², Nur Shazyani Binti Mohd Salleh² \\ 1Universiti Utara Malaysia, Malaysia \\ 2Universiti Tenaga Nasional Bandar Muadzam Shah, Malaysia \\ *kayllnt@yahoo.com
}

\begin{abstract}
The purpose of this study is to establish the relationship between the effectiveness of the training programs and job performance as perceived by teachers in Malaysia. This study investigates the relationship between the level of effectiveness of training with respect to reaction, learning and behavior outcomes and job performance. 210 respondents from various government schools in Klang Valley had participated in this study through a self-administered survey. The results disclosed that all level of effectiveness have significant relationship with job performance. Therefore we can conclude that teachers indeed need and appreciate all the training programs designed by TED currently.
\end{abstract}

Keywords: Training effectiveness, job performance, teachers

\section{Introduction}

With globalization, professional teacher development has become an increasingly challenging. With the growing needs and expectations of the society, teachers are not only expected and seen as imparters of knowledge but also to shoulder the responsibility of molding and shaping a better citizenry. At the same time, teachers also are under a growing pressure to perform. Higher expectations and greater needs from all stakeholders involved now pressuring teachers to perform effectively in classroom. Even the most prepared and genuinely qualified teacher still has a lot to learn in providing high quality education to students. Hence, it is vitally essential that teachers are well prepared in their skills and competencies as this is a continuing process. Teachers must continue to improve their knowledge and skills throughout their careers. The situation began more tensely lately when there are many allegations saying that the teachers are lack of high quality teaching which affecting their performance. Failure to provide adequate training to aid teachers in teaching will lead to the higher social problems that involved students at large. For example, teachers are appeared to be ineffective or less effective in teaching heavier subjects like Science, Mathematics and English. Apart from that, school in the country mainly oriented to the examination. Malaysian Examinations Council (MEC) chairperson Datuk Dr Mohd Noh Dalimin said in terms of schools' performance, government schools showed a drop compared to the previous year, namely, the minimum CGPA of government schools in 2011 was 2.29 compared to 2.32 the previous year. The Teacher Education division is a department within the Malaysian Ministry of Education, which oversees the teacher training education in the country. Much training had been proposed to be carried out for the benefits of teachers. Despite this, very few studies have been focused on the effectiveness of training programs and teacher performance and the results are inconsistent and inconclusive. Teachers are still uncertain whether the training they received really can help them to improve their quality of teachings. Not surprisingly, since teacher, performance is considered complex and remains difficult to predict and little empirical research has actually been conducted to see the effectiveness of training programs, especially from the perspectives of teachers. Therefore, the purpose of this study is to evaluate the effectiveness of training for secondary school teachers in Malaysia.

\section{Literature Review}

It is frequently expressed that job performance is a function of ability and motivation (Campbell and Pritchard, 1976). Performance can be regarded as almost any behavior, which is directed toward task or goal accomplishment. Good performance among employees in an organization has many implications such as high motivation among employees, outstanding ability, good organizational climate and infrastructure, excellent leadership that can sustain rapport and productivity and good relationship among staff. This refers the positive quality of producing good products and in this case, good students' performance. Noe (2002) defines training as planned activities on the part of the organization targeted towards increasing the job knowledge and skills or to modify the attitudes and behaviors of employees in 
ways consistent with the goals of organization and the requirements of the job. Training consists of organized learning activities capable of improving individual performance through changes in knowledge, skills or attitude (Huang, 2001). Hubbard (1995) suggests that all training programs should be evaluated. There are many reasons as to why it is essential that training is evaluated. According to Kraiger, Ford and Salas (1993) the most important reason is to discover if learning has taken place in the training session. Learning can taken place mentally, emotionally or by a change in the level of skill a person acquires. A vital training program provides updates and enhances the skills that make staff successful in the current workplace (Gavin 2001). Effectiveness as a criterion for evaluation implies the attainment of the training program objectives. Specifically, training effectiveness investigates the effectiveness of training programs with respect to reaction, learning and behavior outcomes, stated Kirkpatrick (1959; 1996). Reeves (1994) stated that effectiveness, as a criterion for training evaluation is an important factor to ensure that a training program has achieved the predetermined objective towards qualitative performance. The Teacher Education division (TED) is a department within the Malaysian Ministry of Education, which oversees the teacher training education in the country. In order to support its aspirations for the achievement of its national target to become a 'developed country' the TED has taken up the task to develop its teachers. The TED carries out its various operations with the help of the Planning and Policy Unit, which plans and determines the direction of teacher education. TED also plans and coordinates ongoing teachers both locally and overseas to enhance the quality of its training.

Noran \& Habibah (1999) studied job motivation and job performance of recipients for excellent service from one of the institutions of higher learning. The objectives of their studies were to determine job motivation and job performance of the recipients and also to compare job motivation according to gender and work category. The results showed that the overall job motivation was moderate, while job performance was high. Achievement motivation becomes the driving factor for future understanding and can be defined as a predisposition to strive for success. Deci, Connell \& Ryan (1989), add that teachers who possess autonomy motivation exhibit less stress and have high job satisfaction compared to teachers who have low autonomy motivation. The larger the gap between the skills required and those possessed by the employees, the greater the lack of job satisfaction of the employees and the turnover intentions. Although there has been no direct link in the literature between training and job performance, Rowden (2002) and Rowden and Conine (2005) propose that training may be used as a tool to increase job satisfaction. Rowden and Conine (2005) argues that trained employees will better satisfy the needs of their customers. Tsai, Yen, Huang \& Huang (2007) found that employees committed to learning showed a higher level of job satisfaction with a positive effect on their performance. The selection of an evaluation model is very important in relation to what the training provider aims to get out of it, according to AlAthari and Zairi (2002). They also found out that $67 \%$ out of 300 US organizations are using Kirkpatrick model for this model provides the ability to measure training quality correctly, accurately and skillfully. Kirkpatrick (1996) posits that four general dimensions with which to evaluate training effectiveness: (1) reaction; (2) learning; (3) behavior; and (4) results. This research paper uses the first three levels of Kirkpatrick's model were measured through participant's "reaction" to the training program, amount of "learning" as gouged by knowledge acquired and skills improved and the extend of on-the-job "behavior" changes. These effectiveness levels were used as the independent variables for this study, correlating them to job performance. The research model is drawn out as below:

Figure 1: Theoretical/conceptual framework Independent Variables

Dependent Variables

\begin{tabular}{|c|c|}
\hline $\begin{array}{l}\text { Training Effectiveness } \\
\text { Kirkpatrick, (1959) } \\
\text { 1. } \quad \text { Reaction } \\
\text { 2. Learning } \\
\text { 3. } \text { Behavior }\end{array}$ & $\begin{array}{l}\text { Job Performance } \\
\text { Mahoney, Jerdee, and Carroll (1963) } \\
\text { a) Planning } \\
\text { b) Investigating } \\
\text { c) Coordinating } \\
\text { d) Evaluating } \\
\text { e) Supervising } \\
\text { f) Negotiating } \\
\text { g) Representing } \\
\text { h) Overall performance }\end{array}$ \\
\hline
\end{tabular}

Parallel to the objectives of this paper and research framework and consistent with the relevant literature, this paper proposes to test the following hypothesis: 
H1: There is a positive relationship between training effectiveness and job performance.

H2: There is a positive relationship between reaction and job performance.

H3: There is a positive relationship between learning and job performance.

H4: There is a positive relationship between behavior and job performance.

\section{Methodology}

Targeted participation for this study was the teachers who teach in public secondary schools in Selangor area. The researcher uses the method of convenience sampling due to time constraint. A total of 210 teachers had been invited to participate in this research; a self-administered written questionnaire was used to collect data for this study. The total number of usable questionnaire is 192. Therefore, the response rate for this study is 91\%.The data used for this study were adapted through Kirkpatrick, (1959) for the components of training effectiveness and Mahoney, Jerdee and Carroll (1963) on job performance. The survey consists of three parts. Section A was developed to measure the demographic information of the individual employees such as age, gender, highest level of education, length of working experiences after leaving school and length of current employment. Section B was designed to measure the independent variable of the training effectiveness. The questions have 19 items (Question 1-19) and were divided into three sub-variables. First sub-variable in training effectiveness is reaction, was measured in question 1-8. Second sub-variable is learning, which was measured through question 9-13 and last sub variables is behavior were measured in question 14-19. Section C was designed to measure dependent variables of the job performance. The questions have an eight items; planning, investigating, coordinating, evaluating, supervising, negotiating, representing and overall performance. All the questionnaires were on five likert-scales which (1) represent strongly disagree, (2) disagree, (3) neutral, (4) agree, (5) strongly agree.

\section{Results and Discussion}

Most of the respondents are between 20 to 30 years old (32.8\%), followed by $31.3 \%$ from respondents between 31 to 40 years, $22.9 \%$ were respondent from 41 to 50 years and lastly, $13 \%$ were respondent between 51 to 60 years. Between male and female, the higher frequency is fall to female, which equal to 146 people. While male just only 46 people or $24 \%$. Next, the third demographic is level of qualifications. Most of the respondents possessed their tertiary education, 99.5\%. Only one respondent possessed diploma $(0.5 \%)$. The last demographic is the length of current employment. Teachers had over 16 to 20 years in their current job is $29.7 \%$. The years of service for $11-15$ years reported were $25.5 \%$, followed by $19.8 \%$ teachers in 6 to 10 years of service. The others $24.5 \%$ have been working at their current job within 1 to 5 years and lastly $5 \%$ teacher less than 1 year.

Table 1: Respondents' Profile

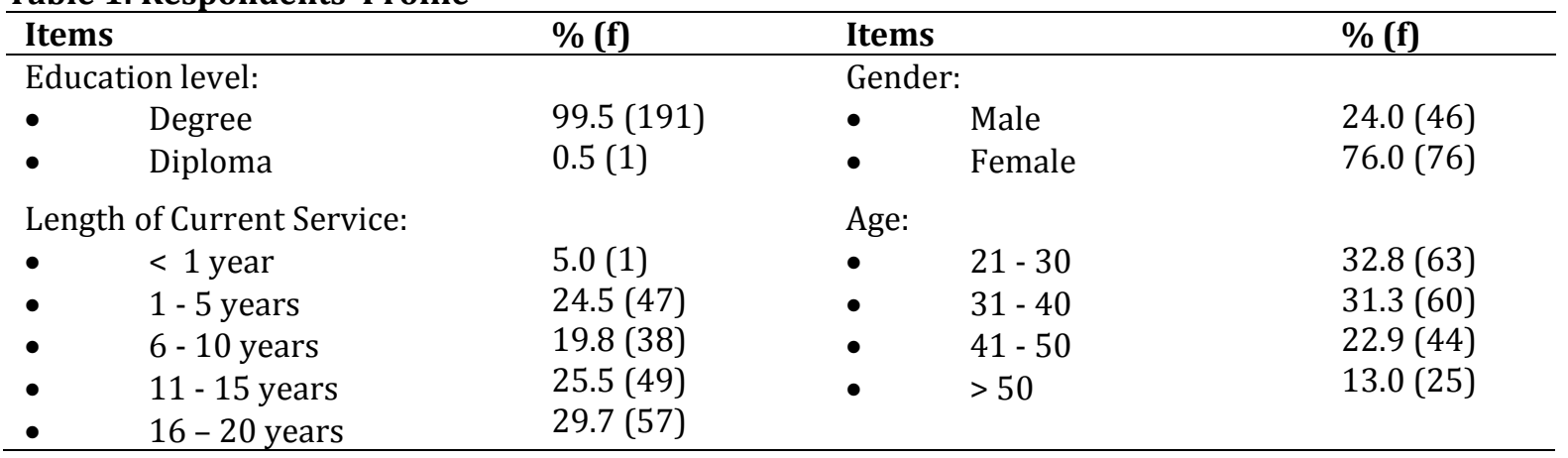

Table 2: Cronbach Alpha Value

\begin{tabular}{ll}
\hline Item & Cronbach Alpha (No. of items) \\
\hline Reaction & $0.884(8)$ \\
Learning & $0.799(5)$ \\
Behavior & $0.812(6)$ \\
Job Performance & $.895(8)$ \\
\hline
\end{tabular}


Table 2 presents Cronbach alpha value for each dimension used in the study. All of the Cronbach alpha values were more than 0.7 which indicate that the dimensions used for each variable are highly reliable (Hair, Bush \& Ortinau, 2006; Nunnally, 1978).

Table 3: Correlation analysis of overall training effectiveness and job performance

\begin{tabular}{llllll}
\hline & TE & reaction & learning & behavior \\
\hline JP & Pearson Correlation & $.346^{* *}$ & $.396^{* *}$ & $.237^{* *}$ & $.264^{* *}$ \\
& Sig. (2-tailed) & .000 & .000 & .001 & .000 \\
N & 192 & 192 & 192 & 192 \\
\hline
\end{tabular}

**. Correlation is significant at the 0.01 level (2-tailed).

Table 3 shows the results of correlation analysis used to identify the relationship between training effectiveness and job performance. The correlation of between training effectiveness and job performance is significant at .346. Thus, there is a relationship between training effectiveness and job performance. Therefore, $\mathrm{H} 1$ is accepted.H2 tries to identify the relationship between reaction and job performance. The correlation of both variables is significant at 0.396 . Thus, $\mathrm{H} 2$ is accepted. In H3, is to identify the relationship between learning and job performance. Result shows that there is relationship between learning and job performance since the correlation is significant at 0.237 . This proved that there is relationship between these two variables. Therefore, $\mathrm{H} 3$ is accepted. In $\mathrm{H} 4$, is to identify the relationship between behavior and job performance. From the result, the relationships have seen as significant at 0.264 . This shows that both variables are related and there are relationships between behavior and job performance. Therefore, $\mathrm{H} 4$ is accepted. From this finding, it is proved that training can give good impact in teacher's improvement. Allen (2007) found that teacher training is a kind of adult learning that needs personal process. It means that the training must give the context shape what the teachers needs and wants to learn and, to a somewhat lesser extent, when and where learning takes place. The participants must involve themselves in problem of knowledge transfer. When teachers learn new skill or attitude, they must think about the problems that will be possible occur in the class. It is also stated that training can be "transfer of learning" - an important element in any leadership development initiative. The results revealed that the teachers in this study identified the training program as being a source of influence for their teaching. This finding is similar to Herlina (2011) study, which found that in service training program were reported by the teachers to be by far the biggest source of influence on their decision in teaching, inspiring them to change their teaching and beliefs. It means that the teacher in this study had commented that they found the experience of attending the training program is useful and informative.

\section{Conclusion}

As a conclusion this study contributes new finding to the issues of effectiveness of training programs as perceived by teachers. Based on the result from the data analysis, researcher can be concluding that, all the training effectiveness levels did influence on job performance. It will help both employees and also employer to know what can be done in order to have a good in job performance after join the training. The findings of this study further can help TED to make sound training investment decisions, it can help the teacher's training to ensure that courses are working, and also help ministry to identify barriers that are preventing skills from being applied, and help the stakeholders be confident that the hours its employees spend in training and the dollars that it invests in its people are time and money well spent. The information on the relationship between training effectiveness and job performance is still narrow. Due to that, it is suggested to all researchers to explore this field since the knowledge on training effectiveness towards job performance is really important in this era. It is recommended for the researchers to extend this research to a larger scale, possibly to whole Malaysia. Secondly, author may consider conducting the study on longitudinal basis in investigate the impact of training effectiveness and job performance at higher education level. 


\section{References}

Al-Athari, A. \& Zairi, M. (2002). An empirical study of the impact of knowledge management on organizational performance. Journal of Computer Information Systems, 42, 74-82.

Allen, S. J. (2007). Adult Learning Theory and Leadership Development. Kravis Leadership Institute, Claremont McKenna College, 7, 26-37.

Campbell, D. J. \& Pritchard, R. (1976). Motivation theory in industrial and organizational psychology. In M.D. Dunnette (Ed.), Handbook of industrial and organizational psychology (63-130). Chicago: Rand McNally.

Deci, E. L., Connell, J. P. \& Ryan, R. M. (1989). Self-determination in a work organization. Journal of Applied Psychology, 74, 580-590.

Gavin, T. (2001). 2001 Industry Report. Training, 38(10), 40-75.

Hair, J. F. J., Bush, R. P. \& Ortinau, D. J. (2006). Marketing research: Within a changing information environment, McGraw Hill International Edition.

Herlina, W. (2011). The effectiveness of Indonesian English teachers training programs in improving confidence and motivation. International Journal of Instruction, 4(1).

Huang, T. C. (2001). Education + Training. MCB University Press, 43(8/9), 437-444.

Hubbard, A. (1995). A Price Tag on Training. Mortgage Banking, 55(5).

Kirkpatrick, D. L. (1959). Techniques for evaluating training programs. Journal of the American Society of Training and Development, 13, 3-9.

Kirkpatrick, D. L. (1996). Invited reaction: Reaction to Holton article. Human Resource Development Quarterly, 7, 23-25.

Kraiger, K., Ford, J. K. \& Salas, E. (1993). Application of cognitive, skill-based, and affective theories of learning outcomes to new methods of training evaluation. Journal of Applied Psychology, 78, 311328.

Mahoney, T. A., Jerdee, T. H. \& Carroll, J. S. J. (1963). Development of managerial performance: A research approach. Cincinnati: Southwestern.

Noe, R. A. (2002). Employee Training and Development (New York: McGraw-Hill Irwin).

Noran, F. Y. \& Habibah, E. (1999). Job motivation and job performance: Case of recipients for excellent service in a higher education institution. Malaysian Management Review, 4(2).

Reeves, M. (1994). Evaluation of training. Petaling Jaya: Pelanduk Publications, 3243.

Rowden, R. W. (2002). The relationship between workplace learning and job satisfaction in small and mid-sized businesses. Human Resource Development Quarterly, 13, 407-26.

Rowden, R. W. \& Conine, C. T. J. (2005). The impact of workplace learning and job satisfaction in small US commercial banks. Journal of workplace Learning, 17(4), 215-30.

Tsai, P., Yen, C. Y., Huang, L. \& Huang, I. (2007). A study on motivating employee is learning commitment in the post-downsizing era: job satisfaction perspective. Journal of World Business, 42(2), 157-69. 